\title{
Reading for entertainment or information reception? Gender differences in reading preferences and their impact on text-type-specific reading competences in adult readers
}

\author{
Kathrin Thums ${ }^{1}$ (D) Cordula Artelt $^{1} \cdot$ Ilka Wolter $^{1}$ \\ Received: 20 September 2019 /Revised: 8 April 2020 / Accepted: 14 May 2020 / \\ Published online: 6 June 2020 \\ (C) The Author(s) 2020
}

\begin{abstract}
This study aims at exploring gender differences in text-type-specific reading competences via readers' gender-specific reading preferences. Women were expected to read more often for the sake of entertainment (entertainment preference), whereas men were expected to read more often to gain information (information preference). We further assumed that individuals who read for entertainment would have higher reading competence in fictional literary texts compared with non-fictional informational texts, and vice versa for individuals who read to gain information. The analysis was based on a sample of 830 adults between 19 and 71 years $(M=31.04 ; S D=12.53)$ from a pilot study of the German National Educational Panel Study (NEPS). A structural equation model confirmed that women and men show different reading preferences during leisure time. The preference to read for entertainment was predictive for reading competence in literary texts; however, the preference to read for information had positive effects on reading competence in both informational and literary texts.
\end{abstract}

Keywords Reading competence · Text-type-specific reading competences · Gender differences · Preferences to read $\cdot$ Reading behavior

Reading comprehension is a basic key competence for adults as well as for children and adolescents and is assumed to be indispensable for an active participation in various fields, including social life,

Kathrin Thums

kathrin.thums@lifbi.de

Cordula Artelt

cordula.artelt@lifbi.de

Ilka Wolter

ilka.wolter@lifbi.de

1 Leibniz Institute for Educational Trajectories, Wilhelmsplatz 3, 96047 Bamberg, Germany 
education and the labor market. Furthermore, reading is a key to learning and achievements in other domains since knowledge is largely accessible through text and discourse (Artelt et al. 2007; Organisation for Economic Co-operation and Development, OECD 2013, 2019). In this article, reading competence is conceptualized as reading literacy as defined in international large-scale assessments (LSA; e.g., PISA or PIRLS; cf. OECD 1999).

These LSA studies have revealed gender differences in reading competence between children and adolescents, whereas gender differences are small to non-existent in adulthood. Furthermore, a consistent pattern of gender differences in reading for children and adolescents, but not for adults, has become evident: In general, female students consistently prove to be more competent in reading than male students (Chiu and McBride-Chang 2006; Klieme et al. 2010; OECD 2019; Reiss et al. 2016).

Previous research suggests that specific features of the assessments are relevant for gender differences in reading competences. For example, the PISA study (OECD Programme for International Student Assessment) follows a design which is more in favor of girls due to the selection of continuous and literary texts (Solheim and Lundetræ 2017; Stanat and Kunter 2002). However, the reading assessment in the PIAAC study (Programme for the International Assessment of Adult Competencies), which is addressed to adult readers, consists of non-fiction texts and does not include narrative literary texts (OECD 2013; Solheim and Lundetræ 2017). Non-fiction texts are considered to be in favor of men over women, which might explain the small to non-existent gender differences in adults' competences in PIAAC (Solheim and Lundetræ 2017). Therefore, the focus of this study is not the general reading competence of women and men, but rather expands previous research on adults' reading competence by investigating gender differences in text types such as informational and literary texts (cf. Artelt and Schlagmüller 2004; Roick et al. 2013; Stanat and Kunter 2002).

However, a proficient reader is not only skilled in understanding texts and extracting relevant information, but also has a positive attitude towards reading (e.g., Artelt et al. 2010; Groeben 2004). This wider view of the concept of competence, including reading attitudes and motivational disposition, is also implemented in other frameworks and conceptualizations (e.g., Weinert 2001) and underlines the interdependence of motivation and achievement. Thus, the connection between the cognitive aspect of reading (reading competence) and the behavioral component based on reading preference might be a possible explanation for gender differences in reading competence. We expect that women and men have different reading preferences during leisure time. In particular, we argue that individuals' reading preferences during leisure time should predict gender differences in text-type-specific reading competence. Still, previous studies have not yet investigated whether gender differences in text-type-specific reading competence among adults are explained by gender differences in preferences of reading.

In summary, the present study expands previous research on gender differences in adults' reading competence by investigating reading competences with respect to text-type-specific reading competences. Moreover, the study aims at investigating if gender differences in texttype specific reading competence are mediated by adults' individual reading behavior (i.e., reading preferences during leisure time).

\section{Gender differences in reading competence}

Previous empirical studies on reading competence in different age groups throughout school consistently showed that girls were on average more proficient than boys (e.g., in primary school: Mullis et al. 2012; in secondary school: Klieme et al. 2010; OECD 2019; Reiss et al. 2016).

So far, in all PISA cycles, 15-year-old girls achieved significantly higher reading competence scores than their male peers (OECD 2019). In 2018, girls across all OECD countries 
achieved better reading competence scores than boys; in particular, they performed on average 30 points better than boys in the reading literacy assessment (girls: $M=502$ points, $S D=0.5$; boys: $M=472$ points, $S D=0.6$; OECD 2019). There are only a few studies on reading competences of adults and these reveal less clear results on gender differences in their reading abilities (OECD 2013; Solheim and Lundetræ 2017). The PIAAC study showed that there were no substantial gender differences, on average in the OECD countries, for adults between 16 and 65 years (OECD 2013). However, in PIAAC, the reading assessment is without including reading of narrative literary texts (OECD 2013; Solheim and Lundetræ 2017).

From an empirical point of view, it seems useful to differentiate between text types, e.g., informative texts as a form of expository non-fiction texts, and literary texts as a form of narrative fiction texts (Artelt and Schlagmüller 2004; Mar and Rain 2015; Roick et al. 2013). In order to follow the argument that reading preferences impact reading competence, the structural differences between different text types need to be identified. The textual requirements for reading and understanding expository non-fiction texts and narrative fiction texts also differ with regard to their language and their formal structure and in terms of content (Gardner 2004). Research indicates that literary text competence and informative text competence are distinguishable text-type-specific reading competences and a differentiation of specific text types allows a more precise view on competence differences.

Following this argument, Stanat and Kunter (2002) further analyzed the data from the international PISA sample regarding gender-specific strengths and weaknesses in reading competence scores dependent on text formats (continuous texts and non-continuous texts). The 15-year-old girls performed 0.5 standard deviation better than boys in continuous texts (e.g., continuously written texts such as narrations and arguments); however, they only outperformed boys by 0.1 standard deviation in non-continuous texts (non-continuous information, like charts, diagrams, and graphics). When children's interest in reading was controlled for, there was even a slight advantage for boys in non-continuous texts. Yet, girls' better performance in continuous texts remained significant even when controlling for interest. Therefore, gender differences in reading can also be ascribed to the type and presentation of texts (Stanat and Kunter 2002).

Artelt and Schlagmüller (2004) also differentiated PISA texts with respect to text types. The authors argued that the competent handling of literary texts is a specific aspect of reading competence, because with literary texts, different rhetorical requirements like metaphors or symbols are used. They further categorized continuous texts dependent on their content either to literary texts (narrations, e.g., fable, drama, or parts of novels) or to other continuous texts (e.g., statement, description) and distinguished them from non-continuous texts including charts, tables, and diagrams. The authors hypothesized that girls' better performance in reading is not only due to the text format, but also to the content of texts. It was presumed that reading literary texts is a typical activity for girls, and therefore they should achieve substantial performance advantages on literary texts as compared to boys. Consequently, the advantage for girls in other continuous texts was presumed to be much smaller than with literary texts. However, the results of this study showed that girls were more competent than boys in reading continuous text types, irrespective of the distinction into literary texts and other continuous texts. Additional analysis showed that gender differences in favor of girls were less pronounced when processing non-continuous texts than continuous ones.

To summarize previous empirical results, there were gender differences in reading competence for girls and boys of school age, whereas there were no gender differences in adults' reading competence, though it is important to note that reading abilities, as measured in studies 
with adults cohorts like in PIAAC (16-65 years), do not refer to the same framework of reading comprehension as measured in school-based large-scale assessments such as PISA (cf. Lundetræ et al. 2014), for example narrative texts are not included in PIAAC as compared to PISA (Solheim and Lundetræ 2017). Moreover, less research has been conducted on gender differences in reading competence of adults and, furthermore, those few studies lack a more detailed focus on text types, e.g., narrative texts. Although an increasing number of studies consider the general reading competence of adults, little is known so far about text-typespecific reading competence of adults. As mentioned by Artelt and Schlagmüller (2004) and Roick et al. (2013) as well as Stanat and Kunter (2002), the distinction of specific text types might be relevant when exploring gender differences in reading competence. To our knowledge, the differentiation of text types, however, has never been examined in adults' reading competence. Therefore, this study aims at investigating gender-differentiated reading competence of adults in literary and informational texts.

\section{The impact of reading behavior on reading competence}

Reading and understanding texts play an important role in many areas of everyday life; therefore, the impact of reading behavior on reading competence should be looked at more closely. Previous research showed a positive correlation between reading behavior (or habits, intentions, preferences) and different reading skills (e.g., word reading and recognition, reading comprehension) (Mar and Rain 2015; McGeown et al. 2015; Mol and Bus 2011; Torppa et al. 2019). Pfost et al. (2013) called this reciprocity a "virtuous circle of reading." While the reader makes an authentic reading experience, the development of reading competence is fostered and their reading volume increased (Pfost et al. 2013).

In a meta-analysis with 99 studies $(N=7669)$, Mol and Bus (2011) examined three age groups (kindergarten/pre-school, first-12th grade, and university students). In all three age groups, print exposure correlated $(r=0.30$ to $r=0.65$ ) with different components of reading competence (oral language, reading comprehension, basic reading skills, word recognition, and spelling). With increasing age, the impact of reading volume became more relevant for the comprehension components, especially for oral language and word recognition. Noteworthy is the close link between reading practice and the components of reading competence among students. The authors argued that this high relationship reflects the independent choice of reading and the self-determined selection of leisure activities.

Pfost et al. (2013) also found in a sample with 1226 children (age $M=11.4$ years; $S D=$ 0.46 ) that reading narrative texts or books (novels, narratives, and stories) in their leisure time was the best predictor for the development of reading comprehension and vocabulary. The quantity of newspapers, comics, and non-fiction books was, however, less important for reading competence development. The authors reveled that different texts have different characteristics and thus define different requirements for the readers and their reading comprehension.

Other studies also investigated the role of reading behavior in leisure time for the development of reading literacy, especially of vocabulary, reading speed, and reading comprehension. In a sample of 312 students between 11 and 16 years, McGeown et al. (2015) found that fiction reading was a significant predictor of reading comprehension, summarization skills, and reading speed. In this study, girls reported more fiction book reading than boys. 
Mar and Rain (2015) examined university students at the age of 20 years who were asked to report on their reading habits and preferences, and participate in a recognition test for print exposure. Findings revealed that exposure to narrative fiction was a better predictor for verbal abilities (synonym knowledge, analogies, sentence completion, and reading comprehension) than expository non-fiction.

To sum up, previous research showed a positive impact of leisure time reading behavior on reading competence and we assume that the quantity of reading in leisure time has a positive influence on reading competences (Mol and Bus 2011).

\section{Reading behavior as a readers' characteristics for a positive impact of reading competence}

It should, however, also be noted that reading behavior is very diverse and multifaceted (Christmann 2004; Groeben 2004). In particular, in the area of leisure time reading, when readers can freely choose their reading material as compared to a professional context, a large number of possible genres, topics, and media formats (paper versions or digital formats) are available to readers who can choose freely according to their own interests, habits, and intentions. In our study, we focus on reading preferences in leisure time since it is plausible to assume that the amount of reading and the specific reading material during leisure time reading is more autonomously and voluntary selected than when reading in the work context. We hypothesized that during leisure time, readers select their reading material independently according to their own preferences from a wide range of existing reading material and genres.

Next to focusing solely on characteristics of text features, it is important to also acknowledge the characteristics of readers, for example their reading preferences and prior knowledge, as well as the interaction of text features and readers' characteristics for reading competence (Artelt et al. 2001; Christmann 2004). Consequently, there are fluent transitions between the genres and topics of reading material, as well as the readers' reading behavior, habits and preferences. Thereby, it is plausible to assume that readers pursue multiple intentions with their choices and preferences for reading materials or topics. Groeben (2004) argued in his theoretical model that readers most frequently choose certain text genres based on different reading preferences. Different text genres serve more or less diverse purposes for the reader, e.g., to provide entertainment or to gain information. Hence, the author distinguished two opposite functions of reading texts: entertainment texts (e.g., literary, fictional) and informational texts (e.g., pragmatic, non-fiction). This distinction was described as two separate extremes, but should rather be understood as a continuum since there are also multiple mixed forms of text functions and reader preferences (Groeben 2004).

Understanding and perception of texts as well as fostering esthetic sensitivity and linguistic differentiation are common functions of both entertainment and informational texts. In the narrower sense, this presupposes a corresponding reading competence of the reader. A further common function of reading preferences is enabling the reader to reflect on possible and real worlds (Groeben 2004).

The priority functions of fictional texts (e.g., novels or stories) are entertainment functions at the process level, such as building tension, eliciting joy and sorrow, providing esthetic pleasure, and withdrawing from everyday life (Groeben 2004). 
The predominant functions of informational texts (e.g., non-fiction texts, newspapers, magazines) are aspects of knowledge acquisition, assessment, justification and attitude formation, and evaluation (Groeben 2004).

By reading texts, social and individual consequences are intended for the readers. Entertainment texts mainly foster imagination and strengthen moral awareness. Furthermore, those texts allow the reader to familiarize themselves with topics of diversity and increase their ability to feel empathy. Informational texts essentially foster argumentative communication and (political) opinion formation as well as gaining knowledge (Groeben 2004).

Also, there is an overlap of entertainment and informational functions and genres. Therefore, a categorical separation is difficult in some cases. The distinction in two separate scales is not a distinction in one or the other, rather a value indicating how both functions work relative to each other. The values specify what a reader most often selects from the wealth of possible genres. A reader may have the preference to read both of them equally. Against this background, we assume a positive effect of adults' reading preferences on their reading competence in literary and informational texts.

\section{Gender differences in reading behavior}

A frequently used explanation for gender differences in reading competence is a genderspecific development in terms of reading motivation and interests for reading. Thus, the competence differences have often been attributed to differences in reading interest and enjoyment or intrinsic reading motivation (e.g., Chiu and McBride-Chang 2006; Retelsdorf et al. 2011; Schiefele et al. 2012).

In 2008, the German Foundation for Reading examined 2552 individuals, aged 14 and older. Participants were asked to indicate the frequency of reading periodicals and books. Almost twice as many women as men (37\% vs $20 \%)$ read books for entertainment, whereas men were more likely drawn to realistic facts than women ( $51 \%$ vs $42 \%)$. Compared to men, women more often wanted to forget everyday life (52\% vs $33 \%)$, to be empathic with other figures (31\% vs 19\%), or to escape into another world (28\% vs 17\%) (Stiftung Lesen 2008). These descriptive results coincide with Groeben's (2004) theoretical considerations on the textual functions of entertainment and informational literature.

Furthermore, Charlton et al. (2004) conducted an interview study with 1025 individuals between 16 and 88 years $(M=42$ years) on their emotional engagement with literary texts. They found significant gender differences in the extent to which women and men identify and empathize with the texts and use them to learn about life. The results suggested that women applied different emotional strategies to deal with literary texts. Women seemed to identify more with the characters, to sympathize with the characters, and to use the topics for their own everyday life. In a further analysis, Burbaum et al. (2004) also found that men read more for work than women, and that more women than men used reading to cope with life.

Schreier and Odağ (2004) confirmed in a data re-analysis that women were more involved with fictional texts, whereas men were consistently better at drawing the line between fiction and their everyday lives.

In summary, there is empirical evidence for distinct preferences to read entertainment texts and informational texts (Groeben 2004). Moreover, there are in general gender differences in reading preferences. It seems that women were more involved in the reading material and got further in touch with the content and more often read fiction books for their entertainment. 
Men, however, more strongly differentiated between reality and fiction and were less emotionally involved with what they were reading. Thus, men more often wanted to gain knowledge and facts through the reading material than women (Burbaum et al. 2004; Charlton et al. 2004; Schreier and Odağ 2004).

\section{Research aims and hypotheses}

Against this background, the present study aims to contribute to research on gender differences in adults' reading competence by (a) investigating gender differences in text-type-specific reading competences and (b) taking the varying reading preferences of women and men into account.

Since there is on average no gender difference in general reading competence of adults (OECD 2013), we focus on competences in specific text types (i.e., narrative literary fiction and informational non-fiction texts), because this has not been studied more closely for adults. Previous studies showed that in adolescence, there are gender difference in reading competence and especially in text-type-specific reading competence (Artelt and Schlagmüller 2004; Stanat and Kunter 2002). Therefore, we also expected that if it is possible to distinguish general reading competence into text-type-specific reading competence, different results for women and men become apparent in reading competence of informational and literary texts.

Hence, we expected that reading in leisure time would have a positive impact on reading competence in both text types. However, since there is also empirical evidence for different reading preferences of women and men in their leisure time (Burbaum et al. 2004; Charlton et al. 2004; Schreier and Odağ 2004), we suggest that gender differences in reading competence of literary and informational texts may be mediated by gender-specific reading preferences.

The hypotheses are as follows:

1. There are gender differences in reading competence of literary and informational texts. We expect that women have a higher text-type-specific reading competence in literary texts and men have higher text-type-specific reading competence in informational texts.

2. Reading preferences are related to individuals' reading competences, dependent on text types: Individuals who read for entertainment have higher reading competence in literary texts compared to informational texts.

Individuals who read to gain knowledge have higher reading competence in informational texts than in literary texts.

3. There are gender differences in reading preferences: Women prefer to read to entertain themselves, whereas men are more likely to read for the purpose of knowledge acquisition.

\section{Methods}

\section{Sample and design}

The data was collected within a pilot study of the German National Educational Panel Study (NEPS; Blossfeld et al. 2011). The sample was selected through a predefined quota scheme of 
university students and adults. The categories for the stratified random sampling were age, and education.

Of the 939 study participants in the domain reading, only 900 participants were considered because of an experimental design in which a small subsample was assessed in a different test condition. Furthermore, due to the low number of participants with a migration background $(n=70)$, only those with German as a first language and without a migration background were included in the analyses. This resulted in a final sample of $n=830$ adults between 19 and 71 years $(M=31.04 ; S D=12.53$; exact distribution see Table 1$)$. About half of the participants were female $(n=431 ; 51.9 \%)$. The majority of the sample had an upper secondary school leaving certificate as the highest level of school education in Germany (i.e., Abitur, university entrance degree; exact distribution see Table 1). An exact distribution of the participants by gender, age, and education is available in an open science document: https://osf.io/ma7n5/.

\section{Research instruments}

The study was conducted in the participants' own household with a computer-based assessment of their reading competence and a subsequent questionnaire about their sociodemographic background variables and reading preferences. A trained interviewer was present at the assessment and proctored the testing situation throughout the competence test and questionnaire.

Reading competence assessment A total of 20 texts were used in the pilot study to investigate the reading competence in German. According to the theoretical framework of NEPS, the reading texts cover five different text types: informational texts, commenting or argumentative texts, literary texts, instructional texts, and advertising texts (cf. NEPS framework for assessing reading competence; Gehrer et al. 2013). For the present study, only participants' responses on tasks related to literary and informational texts were analyzed. Therefore, the final material used in the analyses consisted task responses to six informational texts and three literary texts. Task formats were dichotomous multiple choice items and polytomous complex multiple choice items (e.g., ordering items, and cloze items).

In the nine texts, a total of 67 tasks (46 tasks in informational texts, 21 tasks in literary texts) were presented to the participants. The tasks were scaled based on an IRT framework with a

Table 1 Sample distribution in age and highest level of school education

\begin{tabular}{lll}
\hline & $N$ & Percent \\
\hline Age & & \\
19-25 years & 478 & 57.6 \\
26-45 years & 219 & 26.4 \\
46-71 years & 133 & 16.0 \\
Highest level of school education & & 0.2 \\
Did not complete any form of schooling & 2 & 0.6 \\
Special school leaving certificate & 5 & 7.3 \\
Basic Hauptschule leaving certificate & 61 & 4.3 \\
Qualifying Hauptschule leaving certificate & 36 & 16.5 \\
Realschule leaving certificate & 137 & 6.6 \\
University of applied sciences entrance qualification (Fachhochschulreife) & 55 & 64.3 \\
University entrance qualification (Abitur) & 534 & \\
\hline
\end{tabular}


two-parametric logistic model (2PL; Birnbaum 1968) using the ConQuest software package (version 4.5.2; Adams et al. 2015). The reading competence of individuals was provided by a weighted maximum likelihood estimate (WLE) on a logit scale with a mean standardized to zero. Two WLEs for the reading competence were estimated, each for literary texts and informational texts. The prior selection of the tasks was conducted with regard to the item quality (i.e., WMSQ, ICC; cf. Rost 2004) and the discrimination parameters of the items. Moreover, a differential item functioning analysis for testing measurement invariance across women and men was implemented (cf. Pohl and Carstensen 2013). Twelve tasks did not meet the quality criteria (WMSQ $>1.1$; low correlations $<0.20$; DIF between women and men) and were excluded due to their low item quality. As a result, 55 tasks were finally included in the estimation of the WLEs (informational texts, 37 tasks; marginal reliability, 0.70; literary texts, 17 tasks; marginal reliability, 0.60).

Reading preferences in leisure time The preferences of reading material were measured by a questionnaire and operationalized by the prompted reading behavior during leisure time. The participants were asked to indicate from a list of genres how often they usually read these in their leisure time: crime fiction, newspaper, factual books, biography, science fiction, novels, and thriller or horror books on a 5 -point scale $(1=$ never/seldom; $2=$ several times a month; $3=$ once a week; $4=$ several times a week; $5=$ daily). It should be underlined that the questions regarding reading genres were not specified to certain media formats. Since reading preferences in this study were aimed at genres, which can be read in any medial form, we presume that print and digital media are included in this question.

On the basis of the theoretical remarks of Groeben (2004), the genres of science fiction, novels, crime fiction, and thrillers or horror books were categorized into a formative index of the preference to read for entertainment. These genres represent the preference of reading fictional entertainment literature under emotional-motivational aspects as a self-purpose and for entertainment.

The genres of newspaper, factual books, and biography were categorized into the formative index of the preference to read non-fiction informational literature. According to Groeben (2004), they indicate the preference of reading non-fiction in order to obtain information and generate knowledge.

The formative approach of building the indicators was used because the theoretical concept from indicators of preference to read formed the dependent variable of reading competence (Curtis and Jackson 1962; Weiber and Mühlhaus 2014). The two indicators of preference to read form two independent scales. Consequently, readers might have high or low values on both scales or show a mixed pattern of reading preferences.

Choices of reliability tests of a formative model are severely limited. The reliability test in a reflexive model (e.g., Cronbach's alpha) aims for a high correlation between the tasks of an indicator. The indicators of a formative model, however, should be broadly independent from each other. The variance inflation factor (VIF) is therefore used to control the quality of indicators in a formative model (Weiber and Mühlhaus 2014). Diamantopoulos and Riefler (2008) suggested a cutoff value for the VIF from $>5$.

In the analyses for this study, the correlations of the indicator of preference to read for entertainment were between $r=0.12$ and $r=0.53$ (thriller or horror books and crime fiction). The VIF values were between 1.04 and 1.45. The correlations of the indicator of preference to read for information were between $r=0.13$ and $r=0.18$. The VIF values were between 1.02 and 1.03 . 
Both the correlation matrix and the VIF values did not point to the presence of multicollinearity. Therefore, formative indicators of the preference to read for entertainment and the preference to read for information were provided.

Control variables Various studies have shown that reading competence is associated with the number of books at home (e.g., Chiu and McBride-Chang 2006); therefore, we decided to use the number of books at home as control variable. The number of books at home was measured on a 6-point scale (from 0 to 10 books to more than 500 books).

Furthermore, due to the wide span of age in the sample (19-71 years), participants' age was also included as a continuous control variable in the model.

\section{Analysis strategy}

A mediation model was computed with reading competence in literary and informational texts as dependent variables, preferences to read for entertainment or information as mediator variables, and participants' gender as predictor variable. Gender was included as effect coded variable $(-0.5=$ female; $0.5=$ male $)$. The number of books at home and age were grand-mean centered and entered as control variables in the model.

The analysis of the mediation model was conducted using the software Mplus (edition 7; Muthén and Muthén 2017). The Mplus syntax with the model output is available under https://osf.io/ma7n5/.

To test the significance of indirect effects in the model, the product of two direct paths needs to be interpreted. However, the products of direct paths are usually not normally distributed; therefore, conventional significance tests (e.g., joint significance test, Baron and Kenny 1986) have only limited reliability. To address this problem in the mediation model, a standard non-parametric bootstrapping method was used to estimate the four indirect effects and 1000 bootstrap samples were drawn (cf. MacKinnon 2013).

Furthermore, to handle the missing values in the mediator variables, a full information maximum likelihood (FIML) estimator was used (Allison 2009; Enders and Bandalos 2001). The amount of missing data was overall very low and ranged between $2.5 \%$ (preferences to read for information) and $2.7 \%$ (preferences to read for entertainment), and $0.2 \%$ for the number of books at home.

\section{Results}

\section{Descriptive statistics}

Table 2 displays the means and standard deviations of the WLEs for reading competence in literary texts and informational texts, the preferences to read for entertainment and information, and the control variables' number of books at home and individual's age. The descriptive statistics are displayed for the whole sample and separated by gender. Furthermore, the $t$-values for the mean gender difference are included in Table 2. Since reading preferences were measured with formative indicators, sum values were provided for both variables. These two sum values cannot be compared with each other because a different number of tasks were included in the calculation of those values. Each reading preference should therefore be considered a separate scale regarding gender differences in text-type-specific reading competences. 
Table 2 Sample size, mean, and standard deviations for the dependent, mediator, and independent variables as well as mean differences for women and men

\begin{tabular}{lllllll}
\hline & $N$ & $M(S D)$ & $M_{\text {Female }}(S D)$ & $M_{\text {Male }}(S D)$ & $t(d f)$ & $d$ \\
\hline $\begin{array}{l}\text { Reading competence } \\
\quad \text { in literary texts }\end{array}$ & 754 & $0.02(1.48)$ & $0.07(1.21)$ & $-0.02(1.23)$ & $0.99(752)$ & -0.07 \\
$\begin{array}{l}\text { Reading competence } \\
\quad \text { in informational texts }\end{array}$ & 829 & $0.02(1.23)$ & $-0.03(1.11)$ & $0.07(1.11)$ & $1.40(827)$ & 0.09 \\
$\begin{array}{l}\text { Preference to read } \\
\text { for entertainment }\end{array}$ & 808 & $6.22(2.53)$ & $6.64(2.52)$ & $5.79(2.48)$ & $4.83 *(806)$ & -0.34 \\
$\quad \begin{array}{l}\quad 4 \text { variables, sum score) } \\
\text { Preference to read }\end{array}$ & 809 & $6.50(2.32)$ & $6.30(2.31)$ & $6.75(2.31)$ & $2.77 *(807)$ & 0.20 \\
$\quad$ for information & & & & & & \\
$\quad(3$ variables, sum score $)$ & & & & & & \\
$\begin{array}{l}\text { Number of books at home } \\
\text { Age }\end{array}$ & 828 & $3.62(1.43)$ & $3.68(1.40)$ & $3.55(1.46)$ & $1.23(826)$ & -0.09 \\
\hline
\end{tabular}

Gender coding: $-0.5=$ female; $0.5=$ male; coding for preference to read: $1=$ never/seldom, $2=$ several times a month, 3 = once a week, $4=$ several times a week, $5=$ daily; coding for books: $1=0-10$ books, $2=11-25$ books, $3=26-100$ books, $4=101-200$ books, $5=201-500$ books, $6=$ more than 500 books

Reading competence scaled as a weighted maximum likelihood estimate (WLE) on a logit scale with an average mean of zero

$* p<0.05$

The descriptive analyses showed no gender differences in reading competence in literary and informational texts. Furthermore, there were significant gender differences in reading preferences. As expected, women read more often for entertainment (science fiction, novels, crime fiction, and thrillers or horror books) than men. However, men have a significantly higher reading preference for informational texts (newspaper, factual books, and biography) than women. Moreover, there were no significant gender differences in the control variables (i.e., number of books at home and age).

A bivariate correlation matrix with all included variables of the final model is presented in Table 3. The correlations of the included variables range from $r=0.00$ to $r=0.64$ with relatively low coefficients. There was one exception; the correlation between reading competence in literary texts and informational texts $(r=0.64)$ was rather high; however, they still represent separate constructs. The correlation between the two separate scales of reading preferences for entertainment and information was very low $(r=0.07)$. The correlations between reading competence in informational texts and reading preferences were $r=.14$ for preference to read for entertainment and $r=.22$ for preference to read for information. The correlations between reading competence in literary texts and reading preferences were $r=.18$ for preference to read for entertainment and $r=.20$ for preference to read for information.

\section{Mediation model}

Analyses of direct paths The mediation model (see Table 4 and Fig. 1) showed a small gender difference in reading competence in informational texts after including reading preferences and control variables. In that case, men had slightly higher reading competences in informational texts than women $(b=0.15, S E=0.07, p=0.04, d=0.14)$, although there was no gender difference in the reading competence in literary texts $(b=-0.02, S E=0.08, p=$ 0.82 ). So the first hypothesis was partly confirmed, that there are small gender differences in 
Table 3 Correlations between all variables of the final model

\begin{tabular}{llllllll}
\hline & Variables & 1 & 2 & 3 & 4 & 5 & 6 \\
\hline 1 & Reading competence in literary texts & - & & & & \\
2 & Reading competence in informational texts & $0.63^{*}$ & - & & & & \\
3 & Preference to read for entertainment & $0.18^{*}$ & $0.14^{*}$ & - & & & \\
4 & Preference to read for information & $0.20^{*}$ & $0.22^{*}$ & $0.07^{*}$ & - & & \\
5 & Gender & -0.03 & 0.05 & $-0.17^{*}$ & $0.09^{*}$ & - \\
6 & Number of books at home & $0.33^{*}$ & $0.37^{*}$ & $0.32^{*}$ & $0.33^{*}$ & -0.04 & - \\
7 & Age & $-0.26^{*}$ & $-0.28^{*}$ & -0.00 & $0.09^{*}$ & 0.03 & $0.08^{*}$ \\
\hline
\end{tabular}

Pearson correlations, gender coding: $-0.5=$ female; $0.5=$ male; ${ }^{*} p<.05$

informational texts in favor of men, but there were no difference between women and men in reading competence regarding literary texts.

The second hypothesis is related to the research question whether reading competence in text-type-specific reading is predicted by preferences for reading. Individuals who read for entertainment had slightly higher reading competence in literary texts $(b=0.04, S E=0.02, p=$ $0.04, d=0.14$ ), whereas there was no effect from the preferences to read for entertainment on reading competence in informational texts $(b=0.01, S E=0.01, p=0.39)$.

Additionally, there were significant effects from the preference to read for information on the reading competence in literary texts $(b=0.07, S E=0.02, p<0.01, d=0.27)$ as well as on the reading competence in informational texts $(b=0.06, S E=0.02, p<0.01, d=0.27)$. Therefore, hypothesis 2 was partly confirmed because individuals who read for entertainment had a

Table 4 Mediation model: gender differences in text-type-specific reading competences as mediated by preferences to read for entertainment or information

\begin{tabular}{|c|c|c|c|c|}
\hline & \multirow[b]{2}{*}{$b$} & \multicolumn{2}{|c|}{ Model } & \multirow[b]{2}{*}{$d$} \\
\hline & & S.E. & $\beta$ & \\
\hline \multicolumn{5}{|l|}{ Reading competence in literary texts on } \\
\hline Preference to read for entertainment & $0.04 *$ & 0.02 & 0.08 & 0.14 \\
\hline Preference to read for information & $0.07 *$ & 0.02 & 0.13 & 0.27 \\
\hline Gender & -0.02 & 0.08 & -0.01 & -0.02 \\
\hline Number of books at home & $0.24 *$ & 0.03 & 0.28 & 0.58 \\
\hline Age & $-0.03 *$ & 0.00 & -0.29 & -0.67 \\
\hline \multicolumn{5}{|c|}{ Reading competence in informational texts on } \\
\hline Preference to read for entertainment & 0.01 & 0.01 & 0.03 & 0.06 \\
\hline Preference to read for information & $0.06^{*}$ & 0.02 & 0.13 & 0.27 \\
\hline Gender & $0.15^{*}$ & 0.07 & 0.07 & 0.14 \\
\hline Number of books at home & $0.27 *$ & 0.03 & 0.35 & 0.74 \\
\hline Age & $-0.03 *$ & 0.00 & -0.32 & -0.84 \\
\hline \multicolumn{5}{|l|}{ Preference to read for entertainment on } \\
\hline Gender & $-0.79 *$ & 0.17 & -0.16 & -0.34 \\
\hline Number of books at home & $0.57 *$ & 0.06 & 0.32 & 0.79 \\
\hline Age & -0.00 & 0.01 & -0.02 & -0.04 \\
\hline \multicolumn{5}{|l|}{ Preference to read for information on } \\
\hline Gender & $0.50 *$ & 0.16 & 0.11 & 0.23 \\
\hline Number of books at home & $0.54 *$ & 0.06 & 0.33 & 0.73 \\
\hline Age & 0.01 & 0.01 & 0.06 & 0.13 \\
\hline
\end{tabular}

Gender: $-0.5=$ female, $0.5=$ male; control variables: books and age grand mean centred; $d=$ effect size according Cohen's $d$.; * $p<0.05$ 


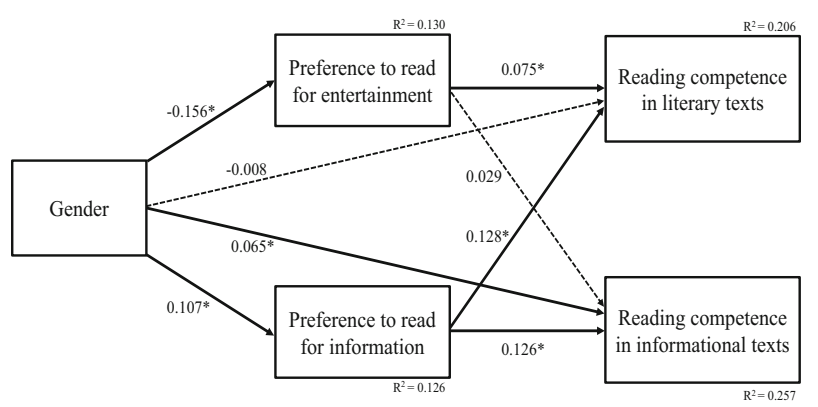

Fig. 1 Mediation model: gender differences in text-type-specific reading competences as mediated by preferences to read for entertainment or information; standardized regression parameters are displayed in the figure; dashed lines are not significant. $* p<0.05$

slightly higher reading competence in literary texts compared to informational texts. However, individuals who read to gain knowledge have higher reading competence in informational texts, yet, opposite to our hypothesis, they also showed higher reading competence in literary texts.

The third hypothesis could be confirmed that there were gender differences in the preferences to read. Women showed a higher preference to read for entertainment (science fiction, novels, crime fiction, and thrillers or horror books; $b=-0.79, S E=0.17, p<0.01, d=-0.34$ ) than men, whereas men preferred to read to gain information (newspaper, factual books, biography; $b=0.50, S E=0.16, p<0.01, d=0.23$ ).

Analyses of indirect paths The indirect paths from gender on text-type-specific reading competences, mediated by reading preferences, were also analyzed. The indirect effects from gender on reading competence in literary texts $(b=-0.03, S E=0.02, p=0.06)$ or on informational texts $(b=-0.01, S E=0.01, p=0.40)$, mediated by the preference to read for entertainment, were not significant. Furthermore, the indirect path from gender on the reading competence in informational texts, mediated by preference to read for information, was significant with a small effect size $(b=0.03, S E=0.01, p=0.01, d=0.17)$. The indirect effect from gender on reading competence in literary texts mediated by preferences to read for information was also significant with a similar effect size $(b=0.03, S E=0.01, p=0.02, d=$ $0.17)$.

\section{Discussion}

The main goal of the study was to explore gender differences in reading competences in literary and informational texts based on different reading preferences of women and men in their leisure time. The study extended previous research on gender differences in pre-school and school age children (e.g., OECD 2019; Stanat and Kunter 2002) by focusing on the reading competence of adults and investigating gender differences in text-type-specific reading competences. Furthermore, the present study focused on an alternative behavioral component, namely reading preference during leisure time, as an explanation of gender differences in the cognitive aspect of reading (i.e., reading competence). 
Interestingly, in this study, there were descriptively no gender differences in adults' reading competence in literary or informational texts. Even though there are only few studies with respect to adults' reading competence, this finding is in line with previous results on gender differences in reading abilities of adults (e.g., PIAAC; OECD 2013).

Furthermore and in line with our hypothesis, the preference to read for entertainment had a significant but small influence on the text-type-specific reading competence in literary texts, but no significant impact on reading competence in informational texts. Additionally, the preference to read for information had an impact on reading competences in both informational and literary texts. The latter was unexpected and is not in line with previous research. Pfost et al. (2013) as well as Mar and Rain (2015) showed for example for children and university students at the age of 20 that reading narrative texts was more important for the development of reading skills than reading expository texts. This inconsistency might be explained by specific characteristics of our sample which consisted of adults and university students with a broader age range (19-71 years) as compared to previous studies (Mar and Rain 2015; Pfost et al. 2013). Moreover, due to an oversampling of university students, our sample is also characterized by high educational attainment. The leisure time reading behavior of university students, as well as adults up to the age of 71, thus, might represent a different meaning than those of secondary school students as investigated by Pfost et al. (2013). Furthermore, the need and necessity of gaining information by reading might be more pronounced in adults than in secondary school students; hence, informational texts, for example newspapers, are in general more often used as reading material. In future research with higher number of participants in various age clusters, it would be interesting to focus on different age ranges in order to obtain more differentiated results on reading behavior and text-type-specific reading competence.

As expected, women read more often for entertainment (science fiction, novels, crime fiction, and thrillers or horror books) in their leisure time, whereas men more often preferred to read to gain information (newspaper, factual books, biographies). These results confirmed previous research which showed that women are in general more involved with the content of their reading material, and eventually more frequently choose fictitious reading material than men in their leisure time. Moreover, prior research revealed that men in general distinguish more strongly between reality and fiction and are not as involved with their reading contents (Burbaum et al. 2004; Charlton et al. 2004; Schreier and Odağ 2004). In the present study, gender differences in reading preferences were assessed by the frequencies of reading specific text genres. Thus, it was possible to ascribe reading preferences to concrete text functions in literary and informational texts.

The findings of the present study also showed that there is no mediated effect of gender on reading competence of literary text when reading for entertainment. Yet, the results confirmed a significant indirect path from gender on both text-type-specific reading competences, mediated by the preference to read to gain information. We expected an indirect effect via the preference to read for information on reading competence in informational texts, but not on the reading competence in literary texts. Thus, the findings showed that adults' reading competence depended more on reading to gain information than reading for entertainment. However, men even caught up slightly to women in their reading competence by preferring to read non-fiction with the purpose to gain information. As a consequence, there was a small gender difference in the mediation model in favor of men in reading competence in informational texts after including preferences and control variables in the model. Simultaneously, these differentiated results of adults' reading preferences and the impact on text-type-specific 
reading competence could also be used to strengthen adolescence interests in reading informational texts.

The finding that reading for information is more important than reading for entertainment stresses the argument that it does not only matter what a reader reads. The preference to read for information might be more related to everyday life of adults than the preference to read for entertainment and with respect to heterogeneous topics and experiences. Since there are multiple functions of non-fictional expository literature (Groeben 2004), for example information reception, opinion formation, and knowledge acquisition, adult readers might be more encouraged to deal intensively with the topics of informational texts as compared to texts which should only entertain and serve as a withdrawal from everyday life. Additionally, the preference to read for information is also included in and associated with job-related reading. Rexing et al. (2015) found in a qualitative survey with adults that reading is more relevant for people in higher positions at the workplace (i.e., superiors compared to apprentices in the building trade) which also might be the case in the present sample of adults with high levels of qualifications. In future studies, the relevance of job-related reading of adults in different types of occupations as well as the distinction from and relation to leisure time reading should be considered more closely. In addition to the presumed relevance of job-related reading behavior for leisure time reading, the amount of reading on the job should also be measured in future studies. This might particularly be relevant since it is possible that individuals, who have to read a lot in their job, read less in their leisure time or seek different leisure time activities.

Moreover, Charlton et al. (2004) found in their study with adults that men search for additional information about what they were reading. Maybe this can also explain the small gender differences in favor of men in reading competence in informational texts. Therefore, in a further study with adults, it would be interesting to ask not only what exactly the preferences for a particular genre are, but also to examine the development of reading preferences for different genres. Additionally, this might also provide information to examine gender differences in reading competence further.

The current study provides an important theoretical contribution to the limited research on adults' reading competence. Nevertheless, the current study also has several limitations. First, the age composition of the sample is very heterogeneous, and the age of participants was not normally distributed due to an oversampling of university students in this study. In addition, there was also, on average, a very high level of education in the sample.

Second, the selection of texts to determine the text-type-specific reading competence was based on only nine texts. Artelt and Schlagmüller (2004) and Roick et al. (2013) showed that it is useful to distinguish between informational texts and literary texts. However, especially with respect to the literary texts, the larger variety of texts within this text type should be included in future studies. Additionally, it might also be interesting for future research to include other text types, for example, commentary or advertising texts as well as non-continuous texts. Similar to the selection of the textual content, there is a limitation in the differentiation of preferences. In future research, it would be advisable to divide the genre into smaller subcategories. A finer graduation of the genres might result in a differentiated effect with regard to reading preferences of women and men.

In conclusion, women and men showed in general different preferences for reading material in their leisure time. However, the different reading preferences of women and men did not explain gender differences in reading competence in literary texts. The gender differences were explained, albeit only slightly, in reading competence of informational texts and in favor of men by reading more often with the preference to gain information. Pfost et al. (2013) reported 
on a "virtuous circle of reading" which referred to the positive influence of reading experience on the development of reading competence and in turn on reading volume. This positive reading experience should be supported and promoted early in education so that the interest and meaning for reading maintained even in adulthood. The results of PISA showed that the overall interests for reading decline over the last PISA decade (Diedrich et al. 2019). This should be intervened already at school by offering a wide range of different reading topics and opportunities. The preferences for reading genres for boys and girls should be promoted in school, however, without enforcing some gender stereotypes by equally providing all topics to both genders.

Yet, the relationship of reading competence and reading preferences is complex; hence, the reciprocity and the direction of this relationship in various text types should be further investigated in future studies to determine the direction of the relationship.

Acknowledgements Open Access funding provided by Projekt DEAL.

Open Access This article is licensed under a Creative Commons Attribution 4.0 International License, which permits use, sharing, adaptation, distribution and reproduction in any medium or format, as long as you give appropriate credit to the original author(s) and the source, provide a link to the Creative Commons licence, and indicate if changes were made. The images or other third party material in this article are included in the article's Creative Commons licence, unless indicated otherwise in a credit line to the material. If material is not included in the article's Creative Commons licence and your intended use is not permitted by statutory regulation or exceeds the permitted use, you will need to obtain permission directly from the copyright holder. To view a copy of this licence, visit http://creativecommons.org/licenses/by/4.0/.

\section{References}

Adams, R. J., Wu, M. L., \& Wilson, M. R. (2015). ACER ConQuest: Generalised item response modelling software [computer software]. Version 4. Camberwell: Australian Council for Educational Research.

Allison, P. D. (2009). Missing data. Sage university papers quantitative applications in the social sciences: Vol. 136. Thousand Oaks: Sage Publ.

Artelt, C., McElvany, N., Christmann, U., Richter, T., Groeben, N., Köster, J., et al. (2007). Förderung von Lesekompetenz - Expertise [promotion of reading competence - an expertise]. Bildungsforschung: Vol. 17. Berlin: Bundesministerium für Bildung und Forschung.

Artelt, C., Naumann, J., \& Schneider, W. (2010). Lesemotivation und Lernstrategien [reading motivation and learning strategies]. In E. Klieme, C. Artelt, J. Hartig, N. Jude, O. Köller, M. Prenzel, et al. (Eds.), PISA 2009. Bilanz nach einem Jahrzehnt (pp. 73-112). Münster: Waxmann.

Artelt, C., Schiefele, U., \& Schneider, W. (2001). Predictors of reading literacy. European Journal of Psychology of Education, 16(3), 363-383. https://doi.org/10.1007/BF03173188.

Artelt, C., \& Schlagmüller, M. (2004). Der Umgang mit literarischen Texten als Teilkompetenz im Lesen? Dimensionsanalysen und Ländervergleiche [The handling of literary texts as aspect in reading? Dimensionality and comparison between countries]. In U. Schiefele, C. Artelt, W. Schneider, \& P. Stanat (Eds.), Struktur, Entwicklung und Förderung von Lesekompetenz. Vertiefende Analysen im Rahmen von PISA 2000 (pp. 169-196). Wiesbaden: VS Verlag für Sozialwissenschaften.

Baron, R. M., \& Kenny, D. A. (1986). The moderator-mediator variable distinction in social psychological research: Conceptual, strategic, and statistical considerations. Journal of Personality and Social Psychology, 51(6), 1173-1182.

Birnbaum, A. (1968). Some latent trait models and their use in inferring an examinee's ability. In F. M. Lord, M. R. Novick, \& A. Birnbaum (Eds.), Statistical theories of mental test scores (pp. 397-479). Reading: Addison-Wesley.

Blossfeld, H.-P., Roßbach, H.-G., \& von Maurice, J. (Eds.). (2011). Education as a lifelong process: The German National Educational Panel Study (NEPS). Zeitschrift für Erziehungswissenschaft/special issue: Vol. 14. Wiesbaden: VS Verlag für Sozialwissenschaften. 
Burbaum, C., Charlton, M., \& Schweizer, K. (2004). Wie und warum liest man Romane? Ergebnisse einer Telefonumfrage zur literarischen Lesekompetenz und zu den Lesestrategien von Erwachsenen [how and why do we read novels? Results of a telephone survey on adults' reading literacy and reading strategies]. Zeitschrift für Medienpsychologie, 16(2), 57-67.

Charlton, M., Burbaum, C., \& Sutter, T. (2004). Lesen Frauen wirklich anders? Oder lesen sie nur eine andere Literatur als Männer? [do women really read differently? Or do they just read a different type of literature than men?]. SPIEL, 23(1), 3-22.

Chiu, M. M., \& McBride-Chang, C. (2006). Gender, context, and reading: A comparison of students in 43 countries. Scientific Studies of Reading, 10(4), 331-362. https://doi.org/10.1207/s1532799xssr1004_1.

Christmann, U. (2004). Information als unmittelbare Funktion des Lesens [information as an immediate function of reading]. In N. Groeben \& B. Hurrelmann (Eds.), Lesesozialisation und Medien. Lesesozialisation in der Mediengesellschaft. Ein Forschungsüberblick (pp. 61-94). Beltz Juventa: Weinheim.

Curtis, R. F., \& Jackson, E. F. (1962). Multiple indicators in survey research. American Journal of Sociology, 68(2), 195-204.

Diamantopoulos, A., \& Riefler, P. (2008). Formative Indikatoren: Einige Anmerkungen zu ihrer Art, Validität und Multikollinearität [formative indicators: Some comments about their type, validity and multicollinearity]. Zeitschrift für Betriebswirtschaft, 78(11), 1183-1196. https://doi.org/10.1007/s11573008-0099-7.

Diedrich, J., Schiepe-Tiska, A., Ziernwald, L., Tupac-Yupanqui, A., Weis, M., McElvany, N., \& Reiss, K. (2019). Lesebezogene Schülermerkmale in PISA 2018: Motivation, Leseverhalten, Selbstkonzept und Lesestrategiewissen [reading-related student characteristics in PISA 2018: motivation, reading behavior, self-concept and reading strategy]. In K. Reiss, M. Weis, E. Klieme, \& O. Köller (Eds.), PISA 2018. Grundbildung im internationalen Vergleich (1st ed., pp. 80-110). Münster: Waxmann.

Enders, C. K., \& Bandalos, D. L. (2001). The relative performance of full information maximum likelihood estimation for missing data in structural equation models. Structural Equation Modeling: A Multidisciplinary Journal, 8(3), 430-457. https://doi.org/10.1207/S15328007SEM0803_5.

Gardner, D. (2004). Vocabulary input through extensive reading: A comparison of words found in children's narrative and expository reading materials. Applied Linguistics, 25(1), 1-37. https://doi.org/10.1093 /applin/25.1.1.

Gehrer, K., Zimmermann, S., Artelt, C., \& Weinert, S. (2013). NEPS framework for assessing reading competence and results from an adult pilot study. Journal for Educational Research Online, 5(2), $50-79$.

Groeben, N. (2004). Einleitung: Funktionen des Lesens - Normen der Gesellschaft [introduction: Functions of reading - norms of the society]. In N. Groeben \& B. Hurrelmann (Eds.), Lesesozialisation und Medien. Lesesozialisation in der Mediengesellschaft. Ein Forschungsüberblick (pp. 11-35). Weinheim: Beltz Juventa.

Klieme, E., Artelt, C., Hartig, J., Jude, N., Köller, O., Prenzel, M., . . Stanat, P. (Eds.). (2010). PISA 2009: Bilanz. nach einem Jahrzehnt [PISA 2009: Results after a decade]. Münster: Waxmann.

Lundetræ, K., Sulkunen, S., Gabrielsen, E., \& Malin, A. (2014). A comparison of PIAAC and PISA results. In A. Malin (Ed.), Associations between age and cognitive foundation skills in the Nordic countries: A closer look at the data (pp. 171-188). Jyväskylä: The Finnish Institute for Educational Research.

MacKinnon, D. P. (2013). Introduction to statistical mediation analysis. New York: Routledge.

Mar, R. A., \& Rain, M. (2015). Narrative fiction and expository nonfiction differentially predict verbal ability. Scientific Studies of Reading, 19(6), 419-433. https://doi.org/10.1080/10888438.2015.1069296.

McGeown, S. P., Duncan, L. G., Griffiths, Y. M., \& Stothard, S. E. (2015). Exploring the relationship between adolescent's reading skills, reading motivation and reading habits. Reading and Writing, 28(4), 545-569. https://doi.org/10.1007/s11145-014-9537-9.

Mol, S. E., \& Bus, A. G. (2011). To read or not to read: A meta-analysis of print exposure from infancy to early adulthood. Psychological Bulletin, 137(2), 267-296. https://doi.org/10.1037/a0021890.

Mullis, I. V. S., Martin, M. O., Foy, P., \& Drucker, K. T. (2012). PIRLS 2011 International results in reading. Chestnut Hill: TIMSS \& PIRLS International Study Center.

Muthén, L. K., \& Muthén, B. O. (2017). Mplus user's guide (8th ed.). Los Angeles: Muthén \& Muthén.

OECD. (1999). Measuring student knowledge and skills: A new framework for assessment. Paris: OECD Publishing.

OECD. (2013). The survey of adult skills: Reader's companion. Paris: OECD Publishing.

OECD. (2019). PISA 2018 results: What students know and can do. Paris: OECD Publishing.

Pfost, M., Dörfler, T., \& Artelt, C. (2013). Students' extracurricular reading behavior and the development of vocabulary and reading comprehension. Learning and Individual Differences, 26, 89-102. https://doi. org/10.1016/j.lindif.2013.04.008. 
Pohl, S., \& Carstensen, C. H. (2013). Scaling of competence tests in the National Educational Panel Study Many questions, some answers, and further challenges. Journal for Educational Research Online, 5(2), 189-216.

Reiss, K., Sälzer, C., Schiepe-Tiska, A., Klieme, E., \& Köller, O. (Eds.). (2016). PISA 2015: Eine Studie zwischen Kontinuität und Innovation [PISA 2015: A study between continuity and innovation. Münster: Waxmann.

Retelsdorf, J., Köller, O., \& Möller, J. (2011). On the effects of motivation on reading performance growth in secondary school. Learning and Instruction, 21(4), 550-559. https://doi.org/10.1016/j. learninstruc.2010.11.001.

Rexing, V., Keimes, C., \& Ziegler, B. (2015). Promotion of reading skills with recipient and domain specific focus - empirical findings in the professional field of construction engineering. Journal of Technical Education, 3(1), 56-74.

Roick, T., Frederking, V., Henschel, S., \& Meier, C. (2013). Literarische Textverstehenskompetenz bei Schülerinnen und Schülern unterschiedlicher Schulformen [literary text comprehension of students in different school types]. In C. Rosebrock (Ed.), Literalität erfassen. Bildungspolitisch, kulturell, individuell (pp. 69-84). Weinheim: Beltz Juventa.

Rost, J. (2004). Lehrbuch Testtheorie - Testkonstruktion [textbook test theory - test construction (2nd, extended and rev. ed.). Bern: Huber.

Schiefele, U., Schaffner, E., Möller, J., \& Wigfield, A. (2012). Dimensions of reading motivation and their relation to reading behavior and competence. Reading Research Quarterly, 47(4), 427-463. https://oi. org/10.1002/RRQ.030.

Schreier, M., \& Odağ, Ö. (2004). Genuss und Distanz: Geschlechtsspezifische Kompetenzen beim Umgang mit Realität(en) und Fiktion(en) [gender-specific competencies at dealing with fiction and nonfiction]. SPIEL, 23(1), 94-115.

Solheim, O. J., \& Lundetræ, K. (2017). Can test construction account for varying gender differences in international reading achievement tests of children, adolescents and young adults? - a study based on Nordic results in PIRLS, PISA and PIAAC. Assessment in Education: Principles, Policy \& Practice, 3 , 1-20. https://doi.org/10.1080/0969594X.2016.1239612.

Stanat, P., \& Kunter, M. (2002). Geschlechterspezifische Leistungsunterschiede bei Fünfzehnjährigen im internationalen Vergleich [an international comparison of gender-specific differences in achievement of 15-year-olds]. Zeitschrift für Erziehungswissenschaft, 4(1), 28-48. https://doi.org/10.1007/s11618-0020003-0.

Stiftung Lesen (2008). Lesen in Deutschland 2008 [Reading in Germany 2008], Mainz.

Torppa, M., Niemi, P., Vasalampi, K., Lerkkanen, M.-K., Tolvanen, A., \& Poikkeus, A.-M. (2019). Leisure reading (but not any kind) and reading comprehension support each other - a longitudinal study across grades 1 and 9. Child Development, 1-25. https://doi.org/10.1111/cdev.13241.

Weiber, R., \& Mühlhaus, D. (2014). Strukturgleichungsmodellierung: Eine anwendungsorientierte Einführung in die Kausalanalyse mit Hilfe von AMOS, SmartPLS und SPSS [structural equation modelling: An applied introduction to causal analysis using AMOS SmartPLS and SPSS (2nd, extended and rev. ed.). Berlin: Springer Gabler.

Weinert, F. E. (2001). Concept of competence: A conceptual clarification. In D. S. Rychen \& L. H. Salganik (Eds.), Defining and selecting key competencies (pp. 45-66). Seattle: Hogrefe and Huber.

Kathrin Thums. Leibniz Institute for Educational Trajectories, Wilhelmsplatz 3, 96047 Bamberg, Germany. Email: kathrin.thums@lifbi.de

Current themes of research:

Reading competence. Competence development. Gender differences in reading competence.

Most relevant publications in the field of Psychology of Education:

No publications yet 
Cordula Artelt. Leibniz Institute for Educational Trajectories, Wilhelmsplatz 3, 96047 Bamberg, Germany.

Current themes of research:

Text comprehension. Reading competence and competence assessment.

Most relevant publications in the field of Psychology of Education:

Artelt, C. (2016). Teacher judgments and their role in the educational process. Emerging Trends in the Social and Behavioral Sciences: An Interdisciplinary, Searchable, and Linkable Resource, 1-16. Wiley. DOI: 10.1002/ 9781118900772.etrds0402

Edossa, A. K., Neuenhaus, N., Artelt, C., Lingel, K. \& Schneider, W. (2018 online). Developmental Relationship between declarative metacognitive knowledge and reading comprehension during secondary school. European Journal of Psychology of Education, 1-20. DOI: 10.1007/s10212-018-0393-x

Pfost, M., Hattie, J., Dörfler, T. \& Artelt, C. (2014, online first). Individual differences in reading development: reviewing 25 years of empirical research on Matthew effects in reading. Review of Educational Research, 84 (2), 203-244. DOI: 10.3102/0034654313509492

Weinert, S., Artelt, C., Prenzel, M., Senkbeil, M., Ehmke, T., Carstensen C.H. \& Lockl, K. (2019). Development of competencies across the life course. In H. P. Blossfeld \& H.-G. Roßbach (Hrsg.), Education as a Lifelong Process (2. Auflage). (S. 57 - 81). Wiesbaden: Springer.

Ilka Wolter. Leibniz Institute for Educational Trajectories, Wilhelmsplatz 3, 96047 Bamberg, Germany.

Current themes of research:

Self-concept and academic achievement. Gender stereotypes and identity. Competence development. Genderspecific learning environments. Reading competence and text comprehension.

Most relevant publications in the field of Psychology of Education:

Ehrtmann, L., \& Wolter, I. (2018). The impact of students' gender-role orientation on competence development in mathematics and reading in secondary school. Learning and Individual Differences, 61, 256-264. doi: 10.1016/j.lindif.2018.01.004

Wolter, I., \& Hannover, B. (2016). Gender role self-concept at school start and its impact on academic selfconcept and performance in mathematics and reading. European Journal of Developmental Psychology, 13, 681-703. doi: 10.1080/17405629.2016.1175343

Bieg, M., Götz, T., Wolter, I., \& Hall, N. C. (2015). Gender stereotype endorsement differentially predicts girls' and boys' trait-state discrepancy in math anxiety. Frontiers in Psychology, 6: 1404. doi: 10.3389/ fpsyg.2015.01404

Wolter, I., Braun, E., \& Hannover, B. (2015). Reading is for girls!? The negative impact of preschool teachers' traditional gender role attitudes on boys' reading related motivation and skills. Frontiers in Psychology, 6: 1267. doi: 10.3389/fpsyg.2015.0126

Publisher's note Springer Nature remains neutral with regard to jurisdictional claims in published maps and institutional affiliations. 